https://doi.org/10.52240/1857-2367.2020.2(21).15

\title{
NECESITATEA APLICĂRII CUNOȘTINȚELOR DE GENETICĂ MOLECULARĂ ÎN GESTIONAREA DURABILĂ A RESURSELOR GENETICE FORESTIERE DIN REPUBLICA MOLDOVA
}

\author{
Dragoș POSTOLACHE ${ }^{1,2}$ \\ ${ }^{1}$ Grădina Botanică Națională (Institut) „,Al. Ciubotaru”, \\ Chişinău, Republica Moldova \\ ${ }^{2}$ INCDS “Marin Drăcea", stațiunea de cercetare din Cluj-Napoca, \\ Cluj-Napoca, România
}

\begin{abstract}
Molecular genetics plays a crucial role in the assessment of forest genetic resources. Using recently acquired genetic knowledge based on molecular markers, can contribute significantly to the development of advanced strategies for in-situ dynamic conservation of forest genetic resources in the Republic of Moldova.
\end{abstract}

Key words: forest genetic resources, chloroplast molecular markers.

Ritmul rapid al schimbărilor climatice asociate cu acțiunile antropice din trecut au condus la creșterea vulnerabilității ecosistemelor forestiere din Republica Moldova, unde au fost observate fenomene de uscare în cadrul populațiilor de fag, frasin și de reducere a frecvenței fructificațiilor în populații de cvercinee.

Pentru gestionarea durabilă a ecosistemelor forestiere afectate de schimbările cli- 
matice sunt necesare cunoștințe genetice privind cuantificarea variabilității genetice inter-populaţionale și intra-populaţionale cu markeri genetici moleculari neutri cum sunt markerii specifici genomului cloroplastic (cpDNA) (Postolache D. et al., 2019).

Studiile genetice efectuate cu markeri moleculari cloroplastici la speciile de cvercinee din România (Popescu F. Postolache D., 2009) au reușit să evidențieze evoluția postglaciară a populațiilor de stejari prin delimitarea rutelor postglaciare de recolonizare și au contribuit la delimitarea regiunilor de proveniență pe considerente genetice.

Astfel, markerii cloroplastici sunt foarte importanți pentru evaluarea proceselor demografice şi studierea diversităţii genetice a speciilor forestiere într-un context regional și european (Popescu F. Postolache D., Pitar D., 2015).

În prezent în Republica Moldova se întreprind activități de identificare și de descriere în teren a noi resurse genetice forestiere şi de evaluare a diversităţii genetice cu markeri moleculari, iar rezultatele vor contribui hotărâtor la dezvoltarea unor noi strategii de conservare dinamică in-situ și de gestionare durabilă a resurselor genetice forestiere pe baza noilor cunoștințe genetice obținute.

Pentru evaluarea variabilității genetice a resurselor genetice forestiere cu markeri moleculari cloroplastici s-au eșantionat probe biologice din cadrul a 22 resurse genetice: de gorun (Quercus petraea), stejar pedunculat (Quercus robur), stejar pufos (Quercus pubescens) și fag (Fagus sylvatica). Probele biologice au fost recoltate din Întreprinderea pentru Silvicultură Hîncești-Silva, Întreprinderea pentru Silvicultură Călărași și Întreprinderea pentru Silvicultură Nisporeni. Din probele biologice recoltate a fost extras ADN-ul genomic total, care a fost folosit pentru genotiparea probelor biologice cu markeri cloroplastici. Primul set de markeri cloroplastici este specific unor regiuni puternic conservate din ADN-ul cloroplastic (cpDNA) și include markerii cloroplastici (DT, CD, AS) care au fost analizaţi cu tehnica PCR-RFLP (engl. Polymerase Chain Reaction Restriction Fragment Length Polymorphism). Setul doi de markeri cloroplastici este de tipul secvențelor repetitive și este specific unor locuși din ADN cloroplastic (cpSSRs) și este constituit din 8 markeri: ccmp2, ccmp6 și ccmp10, $\mu \mathrm{dt} 1, \mu \mathrm{dt} 3, \mu \mathrm{cd} 4, \mu \mathrm{kk} 3$ și $\mu \mathrm{kk} 4$.

Cercetările respective sunt realizate în cadrul proiectului de cercetare și inovare 20.80009.7007.01 „Evaluarea vegetaţiei spontane din Republica Moldova pentru conservarea şi utilizarea durabilă a diversităţii plantelor şi resurselor genetice vegetale în contextul adaptării la schimbările climatice”.

\section{BIBLIOGRAFIE SELECTIVĂ}

1. Postolache, D., Curtu, A. L., Şofletea, N., Popescu, F. (2019). Conservation and Management of Romanian Forest Genetic Resources in the Context of Climate Change. In "Forests of southeast Europe under a changing climate", pp. 389-399. Springer.

2. Popescu, F., Postolache, D. (2009). Variabilitatea genetică a populațiilor de cvercinee din România, rezultat al interacțiunii dintre evoluția postglaciară a vegetației şi influențele antropice. Revista pădurilor 124, 49-54.

3. Popescu, F., Postolache, D., Pitar, D. (2015). Aspecte privind conservarea şi managementul resurselor genetice forestiere din România. Revista de Silvicultură și Cinegetică 21, 13-17. 